\title{
Effects of infection with Toxoplasma gondii oocysts on the intestinal wall and the myenteric plexus of chicken (Gallus gallus) ${ }^{1}$
}

\author{
Rubia dos Santos Bonapaz ${ }^{2}$, Catchia Hermes-Uliana², Franciele do \\ Nascimento Santos ${ }^{2}$, Aristeu Vieira da Silva ${ }^{3}$, Eduardo José de Almeida \\ Araújo $^{2}$ and Débora de Mello Gonçales Sant'Ana ${ }^{2^{\star}}$
}

\begin{abstract}
Bonapaz R.S., Hermes-Uliana C., Santos F.N., Silva A.V., Araújo E.J.A. \& Sant'Ana D.M.G. 2010. Effects of infection with Toxoplasma gondii oocysts on the intestinal wall and the myenteric plexus of chicken (Gallus gallus). Pesquisa Veterinária Brasileira 30(9):787792. Laboratório de Neurogastroenterologia Experimental, Universidade Paranaense, Praça Mascarenhas de Moraes 4282, Centro, Umuarama, PR 87506-140, Brazil. E-mail: debora@unipar.br

This paper aims to analyze the effects of the Toxoplasma gondii infection in the intestinal wall and myenteric plexus of chicken (Gallus gallus). Ten 36-day-old chickens were separated into two groups: control and experimental, orally inoculated with oocysts of the T. gondii strain M7741 genotype III. After 60 days the birds were submitted to euthanasia and had their duodenum removed. Part of the intestinal segments was submitted to histological routine, HE staining, PAS histochemical technique, and Alcian Blue. Qualitative analysis of the intestinal wall and comparative measurements among the groups with respect to total wall thickness, muscle tunic, mucosa, and tunica mucosa were carried out. Caliciform cells were quantified. The other part of the intestinal segments was fixed in formol acetic acid and dissected having the tunica mucosa and the tela submucosa removed. Neurons were stained with Giemsa, counted, and measured. Chickens from the experimental group presented diarrhea and inflammatory infiltrates in the tunica mucosa, thickness reduction of all the parameters assessed in the intestinal wall, and an increase of the number of caliciform cells. There was a $\sim 70 \%$ reduction regarding the intensity of myenteric neurons; and the remaining cells presented a reduction of $\sim 2.4 \%$ of the perikarion and $\sim 40.5 \%$ of the nucleus $(p<0.05)$. Chronic infection induced by $T$. gondii oocysts resulted in intestinal wall atrophy, mucin secretion increase, death and atrophy of chicken myenteric plexus neurons. Death and atrophy of myenteric plexus neurons may be related with the causes of diarrhea observed in chickens with toxoplasmosis.
\end{abstract}

INDEX TERMS: Chicken, toxoplasmosis, duodenum, enteric nervous system, experimental infection.

RESUMO.- [Efeitos da infecção por oocistos de Toxoplasma gondii sobre a parede intestinal e o plexo mientérico de Gallus gallus.] O objetivo deste trabalho foi analisar os efeitos da infecção pelo Toxoplasma gondii

\footnotetext{
${ }^{1}$ Received on September 23, 2009.

Accepted for publication on August 12, 2010.

2 Laboratório de Neurogastroenterologia Experimental, Universidade Paranaense (Unipar), Praça Mascarenhas de Moraes 4282, Centro, Umuarama, PR 87506-140, Brazil. *Corresponding author: debora@unipar.br

${ }^{3}$ Laboratório de Medicina Veterinária Preventiva e Saúde Pública, Unipar, Umuarama, PR.
}

sobre a parede intestinal e o plexo mientérico de Gallus gallus. Dez galinhas de 36 dias de idade separadas em dois grupos: controle e experimental inoculado com oocistos da cepa M7741 de T. gondii (genótipo III) pela via oral. Após 60 dias os animais foram submetidos à eutanásia e o duodeno coletado. Parte dos segmentos intestinais foi submetida à rotina histológica, coloração por HE e técnica histoquímica de PAS e Alcian Blue. Realizou-se uma avaliação qualitativa da parede intestinal e medidas comparativas entre os grupos da espessura da parede total, túnica muscular, muscular da mucosa e túnica mucosa. As células caliciformes foram quantificadas. Outra parte dos seg- 
mentos intestinais foi fixada em formol acético e dissecada retirando-se a túnica mucosa e a tela submucosa. Os neurônios foram corados pela técnica de Giemsa, contados e mensurados. Os animais do grupo experimental apresentaram diarréia e infiltrados inflamatórios na túnica mucosa, redução da espessura de todos os parâmetros avaliados da parede intestinal e aumento do número das células caliciformes. Houve uma redução de $\sim 70 \%$ da densidade dos neurônios mientéricos e as células remanescentes sofreram redução de $\sim 2,4 \%$ do pericário e $~ 40,5 \%$ do núcleo $(p<0,05)$. A infecção crônica induzida por oocistos de T. gondii levou a atrofia da parede intestinal, aumento da secreção de mucinas, morte e atrofia dos neurônios do plexo mientérico de galinhas. A morte e atrofia dos neurônios do plexo mientérico podem estar envolvidas na causa da diarréia observada em galinhas com toxoplasmose.

TERMOS DE INDEXAÇÃO: Galinha, toxoplasmose, duodeno, sistema nervoso entérico, infecção experimental.

\section{INTRODUCTION}

Toxoplasmosis is one of the world's most common parasitary zoonosis. Its etiological agent, the Toxoplasma gondii, is a protozoan presenting a biological cycle facultatively heteroxenous: felines are the definite hosts whereas presumably every homeothermic animal is an intermediary host (Tender et al. 2000). Birds are infected though: (1) ingestion of oocysts eliminated through feline feces; (2) ingestion of tissue cysts (containing bradyzoites); and (3) vertical transmission (transplacentary) of tachyzoites. More often, $T$. gondii can also be transmitted through blood products, organ transplants, and ingestion of tachyzoites from non-pasteurized caprine milk (Tender 1999).

Different $T$. gondii strains are classified as: highly virulent - a single parasite is sufficient to kill a mouse (Genotype I); low virulent - promotes chronic infection in a mouse without needing specific treatment (Genotype II); and intermediary virulence - a parasite is not sufficient to kill a mouse, even though a high dose of sulfonamide is needed to prevent its death (Genotype III) (Freyre et al. 2001). Genotype II and III strains result in chronic infection followed by the consequent formation of tissue cysts mainly on the Central Nervous System (Howe \& Sibley 1995).

The frequency of the parasite upon the population may vary in different regions according to sociocultural habits and geographic and climatic factors (Tender et al. 2000). The identification of $T$. gondii in hen in extensive breeding is a good indicator of the presence of oocysts in the environment as the feeding of such domestic birds occurs through the contact with the soil (Dubey et al. 2002). A number of studies in Brazil present high prevalence of $T$. gondii infection in hen. Garcia et al. (1998) identified a 10.3\% prevalence of the infection in hens in the city of Jaguapitã (State of Paraná, South of Brazil). In this State, in the city of Santa Izabel do Ivaí, $40 \%$ of the hens were found to present positive serology (Dubey et al. 2003), and in another study (Ruffolo et al. 2005) in the same city, a frequency of
$53.49 \%$ of the hen studied were serum reactive. In the State of São Paulo, Southwest of Brazil, Dubey et al. (2002) found $39.02 \%$ of serum reactive samples. In the State of Rondônia, North of Brazil, Dubey et al. (2006) found anti- $T$. gondii antibodies in $66 \%$ of the hens studied which were taken from 11 farms in the region.

Clinically, toxoplasmosis may cause diarrhea in infected birds, and this signal deserves investigation as it harms the nutrition of the animal, and therefore its development. A possible explanation would be because, unknowingly so far, $T$. gondii alters the functioning of the Enteric Nervous System which is responsible for the coordination of intestinal motility (Furness 2006).

Among the studies performed with hens infected with $T$. gondii, Ruiz et al. (2005) verified that they developed severe diarrhea, and Galli et al. (2008) verified that birds infected presented diarrhea when inoculated with oocysts of the Toxoplasma gondii strain M7741 (Genotype III). In order to clarify possible morphological alteration which may lead to diarrhea, the alterations on the wall and myenteric plexus of hen duodenum infected with oocysts of the Toxoplasma gondii M7741 strain for 60 days were assessed.

\section{MATERIALS AND METHODS}

Experimental design. This study was previously approved by the Ethics Committee for Animal Experimentation of Universidade Paranaense (Unipar) (Protocol 10161/2007) in accordance with the norms of Colégio Brasileiro de Experimentação Animal (Cobea). It also meets the orientations presented on the NRC Guide for the Care and Use of Laboratory Animals.

For this fully randomized study, ten 36-day-old Cobb broiler chickens (Gallus gallus) (1.529.0 $\pm 133.77 \mathrm{~g}$ average weight) were obtained from a hatchery in the city of Umuarama, PR. They were submitted to a 10-day adaption period inside pens at the Veterinary Hospital of Unipar. During this period, blood from all birds was collected from the cephalic vein in order to verify the presence of anti-Toxoplasma antibodies using modified agglutination test (MAT) considering as positive the title over 25. Negativity to this test was the criterion for the inclusion of hens in this study. The birds were then weighed, identified with rings, and randomly separated into two groups: Infected Group (IG; n=6) and Control Group (CG; n=4). Feed ${ }^{4}$ and water were supplied ad libitum.

Toxoplasma gondii strain. The Toxoplasma gondii strain M7741 used for the experimental inoculation (in stage of sporulated oocysts) is classified by analyzing the SAG2 gene as Genotype III (Da Silva et al. 2005). The oocysts from the $T$. gondii M7741 strain were obtained through the inoculation of cats with tissue cysts of the parasite, obtained from mice as described by Dubey \& Beattie (1998).

Experimental infection. Control group received no inoculation although it was submitted to all the other procedures for the collection of data and samples. The birds from the experimental group received $1.0 \mathrm{~mL}$ of a suspension containing $10^{3}$ oocysts $T$. gondii strain M7741 genotype III orally.

Euthanasia and collection of biological material. Hens were submitted to euthanasia through cervical dislocation seventy days after inoculation. Blood was collected for the 
verification of the presence/absence of IgG anti-T.gondii through modified agglutination test considering as positive the title over 25. Thus, laparotomy was carried out and the duodenum of each animal removed. This intestinal segment was divided into two parts. They were fixed in Bouin solution for histological processing for the analysis of the intestinal wall and the rest was fixed in acetic formal acid for the whole-mount preparations for the analysis of the myenteric plexus.

Analysis of the intestinal wall. After fixation, the segments were dehydrated in ascending series of etilic alcohol, diaphanized in xilol and included in paraffin for further obtaining 3ìm transversal cuts which were stained with Hematoxylin and Eosin (HE), Periodic Acid Shiff (PAS) for the detection of sialomucins, sulphomucins, and Alcian-Blue (AB) pH1.0 for the detection of sulphomucins, following the protocol described by Myers et al. (2008). Concerning the techniques for the detection of glycoconjugates (PAS and $A B$ ) counterstaining with hematoxylin was performed.

Initially a qualitative analysis of the intestinal wall using slides stained with HE and PAS were carried out. On the first case, it was observed that the organization of the tissues compounding the different layers of the intestinal wall; on the second, it was searched to identify tissue cysts as they elastic wall of this structure contains neutral glycoconjugates (Ferguson \& Dubremetz 2007).

Morphometric analysis of the intestinal wall was conducted from the images of HE-stained cuts captured by a digital camera ${ }^{5}$ attached to a trinocular microscope ${ }^{6}$. These images were used to measure the total thickness of the wall (when captured with the AID of a $4 X$ objective lens), thickness of the tunica mucosa and muscle tunic (when captured with the AID of a 10x objective lens), and the thickness of the mucosa (when captured with the AID of a 40x objective lens). One hundred and twenty measurements of each structure were carried out and uniformly distributed around the hen intestinal circumpherence.

The number of caliciform cells on $0.96 \mathrm{~mm}^{2}$ of each animal's tunic mucosa was quantified. This analysis was performed with slides submitted to histochemical techniques for the detection of glycoconjugates (PAS, $\mathrm{AB} \mathrm{pH} 2.5$ and $\mathrm{AB} \mathrm{pH} 1.0$ ).

Analysis of the myenteric plexus. Duodenum fixed with acetic formol acid was dissected with the aid of a stereoscopic microscope ${ }^{7}$ for the removal of the tunic mucosa and tela submucosa. The remaining layers (muscle tunic and serous tunic) constituted the whole mount. There are two layers of muscle fibers in the muscle tunic in which the myenteric plexus is located and was stained with Giemsa (Barbosa 1978).

The neurons of the myenteric plexus presented organized in different-shape ganglions within both groups. As the myenteric neurons are distributed around the intestinal circumpherence, the segments were divided into three regions for their quantitative and qualitative analysis: mesenteric $\left(0^{\circ}\right.$ $\left.60^{\circ}, 300^{\circ}-360^{\circ}\right)$ antimesenteric $\left(120^{\circ}-240^{\circ}\right)$ and intermediary $\left(60^{\circ}-120^{\circ}, 240^{\circ}-300^{\circ}\right)$, considering the insertion of the mesentery as $0^{\circ}$, as proposed by Miranda-Neto et al. (2001).

By using a photonic microscope ${ }^{8}$ magnifying $400 x$, the neurons within 40 microscopic fields in each region of the intestinal segments were counted. The area of each microscopic field was $0.22 \mathrm{~mm}^{2}$.

The area of the perikarion and nucleus of 100 neurons from the three regions of each animal's intestinal circumpherence totalizing 300 neurons per animal studied was measured for the morphometric analysis. The measurement was conducted with images captured by a digital camera ${ }^{9}$ attached to a $40 x$-objective photonic microscope ${ }^{8}$. Imaging analysis system ${ }^{10}$ was used. The area of the cytoplasm was calculated from the differences between the areas of the perikarion and nucleus. Besides, the ratio between the area of the nucleus and the perikarion of each neuron was determined in order to investigate the proportion occupied by this organelle within the perikarion. The distribution of the neurons in classes with respect to area of perikarion (intervals of $50 \mu \mathrm{m}^{2}$ ) and the ratio between the area of the perikarion and the nucleus (intervals of 0.05 ) was conducted and histograms of frequency were worked out.

Statistic analysis. Numeric data collected initially were submitted to D'Agostino-Pearson or Shapiro test in order to verify the type of distribution. Data presenting normal distribution was presented as mean \pm standard deviation. Student's t-Test was used to compare the groups. Data presenting free distribution are presented as median (percentile 25, percentile 75). The comparison between the groups was performed by the Mann-Whitney test here. For all statistic tests, $P$ values less than 0.05 were considered significant.

\section{RESULTS}

Hens from the control group presented a negative result for the detection of anti-Toxoplasma gondii antibodies whereas the infected group was positive. The infected group presented diarrhea during the experiment.

The presence of inflammatory infiltrates in the tunica mucosa was observed in the duodenum of the birds from the infected group, with prevalence for the following cellular types: fibroblasts, lymphocytes, plasmocytes, and macrophages. Discrete presence of polymorphonuclear (eosinophiles) was also observed in some birds. T. gondii tissue cysts were not found.

Morphometric analysis of the intestinal wall showed that the infection caused by Genotype III T.gondii oocysts provoked the reduction of thickness of the total wall, the tunica mucosa, the muscular mucosa, and the tunica mucosa of GI hen duodenum (Table 1). The dynamic analysis of the glycoconjugates revealed an increase in the proportion of neutral mucins and sialomucins for the group infected with Genotype III T.gondii oocysts (Table 2).

Analysis of the myenteric plexus revealed that the structure was maintained with respect to the organization

Table 1. Initial and final weights, and weight gain in the control group (CG) and of birds inoculated with oocysts of Toxoplasma gondii strain M7741 (IG), observed for 60 days

\begin{tabular}{cccc}
\hline Group & Inicial weight $(\mathrm{g})$ & Final weight $(\mathrm{g})$ & Weight gain $(\mathrm{g})$ \\
\hline CG $(\mathrm{n}=4)$ & $1442.50 \pm 115.29$ & $4511.25 \pm 425.64$ & $3068.75 \pm 436.01$ \\
IG $(\mathrm{n}=6)$ & $1586.67 \pm 119.40$ & $3955.0 \pm 963.65$ & $2368.33 \pm 872.23$
\end{tabular}

\footnotetext{
${ }^{4}$ Cocari $\AA_{\text {, }}$

${ }^{5}$ Moticam 2000, 2.0 Megapixel.

${ }^{6}$ Motic B5.

7 Motic SMZ-140.

8 Motic B5.

${ }^{9}$ Motiam 2000, 2.0 Meapixel.

10 Motic Image Plus versão 2.0, Motic Inc.
} 
Table 2. Thickness of total wall, muscular and mucosa tunics; mean and standard deviation of muscularis mucosa thickness of the control group (CG) and of birds inoculated with oocysts of Toxoplasma gondii strain M7741 (IG), observed for 60 days

\begin{tabular}{lcccc}
\hline Groups & Total wall $(\mu \mathrm{m})$ & Muscular tunic $(\mu \mathrm{m})$ & Muscularis mucosa $(\mu \mathrm{m})$ & Mucosa tunic $(\mu \mathrm{m})$ \\
\hline CG $(\mathrm{n}=4)$ & $556.85(530.78 ; 582.35)^{\mathrm{a}}$ & $293.55(270.70 ; 313.33)^{\mathrm{a}}$ & $25.95 \pm 3.26^{\mathrm{a}}$ & $294.40(268.78 ; 332.73)^{\mathrm{a}}$ \\
IG $(\mathrm{n}=6)$ & $404.20(374.60 ; 444.70)^{\mathrm{b}}$ & $233.30(216.60 ; 250.73)^{\mathrm{b}}$ & $18.73 \pm 2.70^{\mathrm{b}}$ & $205.30(189.70 ; 219.33)^{\mathrm{b}}$
\end{tabular}

Values followed by different letters in the same column indicate significant differences between the groups. Thickness of the muscular tunic, mucous tunic and total wall were compared by Mann-Whitney's test with $\alpha=0.05$. Muscularis mucosa thickness was compared by Student's $t$ for independent samples, with $\alpha=$

Table 3. Mean \pm standard deviation of the number of globets cells evidenced by histochemical techniques for glycoconjugates in a $0.96 \mathrm{~mm}^{2}$ area of the mucosa tunic of the control group (CG) and of birds inoculated with oocysts of Toxoplasma gondii strain M7741 (IG), observed for 60 days

\begin{tabular}{lccc}
\hline Groups & PAS & AB pH 2.5 & AB pH 1.0 \\
\hline CG $(n=4)$ & $967.75 \pm 249.93^{\mathrm{a}}$ & $1134.15 \pm 84.10^{\mathrm{a}}$ & $1169.5 \pm 125.96^{\mathrm{a}}$ \\
IG $(\mathrm{n}=6)$ & $1254.83 \pm 90.67^{\mathrm{b}}$ & $1156.07 \pm 61.58^{\mathrm{a}}$ & $1319.38 \pm 77.64^{\mathrm{b}}$
\end{tabular}

PAS: Periodic-Acid-Schiff; AB: Alcian Blue.

Values followed by different letters in the same column indicate significant differences between the groups by Student's $t$ for independent samples, with $\alpha=0.05$.

of the neurons in the ganglions and that there was a loss of $70 \%$ of the neurons. The remaining cells reduced to $2.4 \%$ of the perikarion and $40.5 \%$ of the nucleus $(p<0.05)$, without significant alt!eration of the cytoplasm area (Table 3).

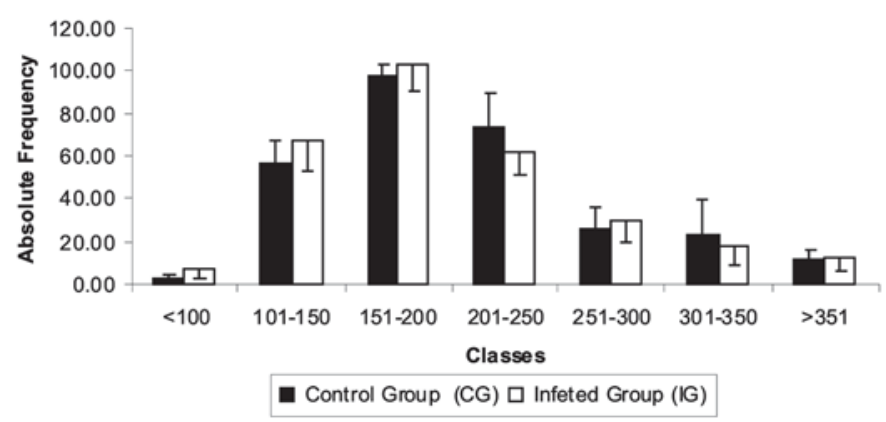

Fig.1. Frequency of myenteric neurons according to perikaryon area intervals of birds of the control group (CG) and of birds inoculated with oocysts of Toxoplasma gondii strain M7741 (IG) observed for 60 day.

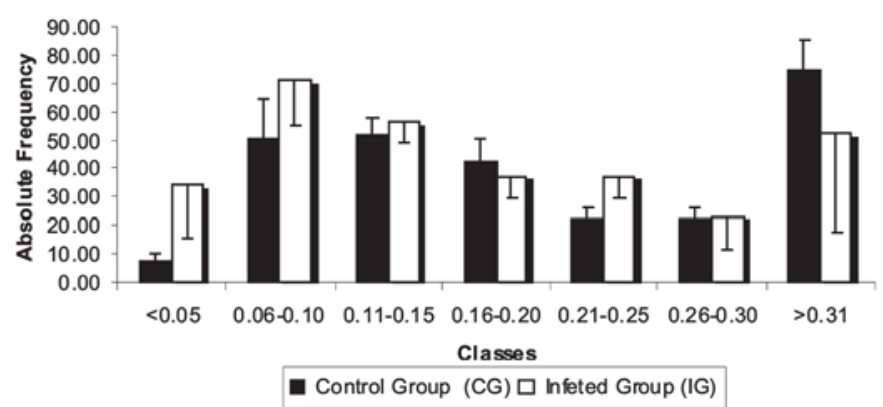

Fig. 2. Frequency of myenteric neurons according to perikaryon to nucleus area ratio intervals of the control group (CG) and of birds inoculated with oocysts of Toxoplasma gondii strain M7741 (IG) observed for 60 days.
Distribution of the frequency of neurons with respect to perikarion area and the ration between the area of the nucleus and perikarion are presented in Figures 1 and 2, respectively, and show that the infection did not alter the specific class of the neurons.

\section{DISCUSSION}

There are a few studies assessing the hen myenteric plexus. In this experiment, the structure of the myenteric plexus in both groups was similar to what was described by Kuder et al. (2003), formed by ganglions of different sizes and shapes, presenting no modifications as a result of the infection. Quantitative analysis of the myenteric plexus revealed a loss of $\sim 70 \%$ of the duodenal neurons. Since methylene blue is a panneural marker, it is deducted that $70 \%$ of the total population of myenteric neurons may have been lost, possibly by the direct action of Toxoplasma gondii or indirectly by chemical mediators modulated on the response to the infection. It is known that IFN-ã and nitric oxide (NO) are among the mediators involved on the infection with protozoans and that they may induce to morphological and quantitative changes of the enteric neurons (Arantes et al. 2004). Former studies with rats orally infected with tachyzoites from a Genotype III T. gondiistrain demonstrated that there was neither diarrhea nor neuronal death during chronic or acute infection, different from what was observed in this experiment (Sugauara et al. 2008). As this has been an exploratory study, new studies are necessary to clarify whether the neurons were lost of partially redistributed as well as which neuronal subpopulation was mostly impaired.

In a former study involving the same hens, the parasite was re-isolated from their brain pool and hearts. From the six infected hens, the parasite was re-isolated in four, with $29.2 \%$ of the mice positive serum and the detection of tissue cysts in $71.4 \%$ (Galli et al. 2008), what confirms the chronicity of the infection in the birds studied.

Neither mortality nor weight gain was observed in this study for none of the groups (Galli et al. 2008) opposite to what was described by Jones et al. (1959) who observed weight loss in experimental toxoplasmosis. Among the ordinary clinical signals of toxoplasmosis only diarrhea, which was not sufficient to alter the gain of body weight during the 60 experimental days, was observed (Galli et al. 2008). It is possible that the cause of diarrhea may be due to either intestinal alterations or bacterial colonization occurred as a result of the inoculum of oocysts used in the experiment was not treated with antibiotics previously. 
The infection with oocysts of Toxoplasma gondii in 5day-old hens resulted in great mortality and the occurrence of diarrhea among the survivors (Ruiz et al. 2005). The survival of the birds in this study and the decreased clinical signals observed may be explained as experiment had started when the hens were 36 days, hence age is an important factor to determine the gravity of the clinical signals and the survival rate of birds infected with T. gondii (Kulasiri 1965).

It was observed in the study that the infection with $T$. gondii induced a generalized reduction of the thickness of the duodenum layers; however, when the ileum of the birds in this study was assessed with respect to the thickness of its intestinal wall layers, only reduction of total wall and tunica mucosa (Shiraishi 20008) was observed. Besides the morphometric alterations, in this study the occurrence of inflammatory infiltrates in the tunica mucosa, characterizing enteritis which, despite of the course of the infection, had not been contained until the moment of euthanasia. Inflammatory infiltrates were also observed in the intestinal wall of mice submitted to oral infection with T. gondii (Rachinel et al. 2004). According to Ferguson \& Dubremetz (2007) when the intermediary host is infected through the ingestion of either tissue cysts or oocysts of $T$. gondii, zoytes are released in the lumen of the small intestine invade enterocytes and intraepithelial lymphocytes and reach the slice itself, in which they differentiate themselves into tachyzoites and invade the cells in that area. When the tachyzoites interact with the mastocytes at the slice, neutrophil, macrophage and lymphocyte chemotaxis is triggered (Ferreira et al. 2004).

These cells were also attracted by molecules secreted by the enterocytes in the basolateral area of the intestinal crypts (Kasper et al. 2004). The recruiting of cells from the immune system to the mucosa can be explained for the inflammatory infiltrates observed at the group inoculated with $T$. gondii and this can be considered the key process for restraining the parasite as it is known that the depletion of neutrophils in mice decreases the organism resistance against the infection with T. gondii (Bliss et al. 2001).

In humans infected with $T$. gondii, diarrhea is also a clinical signal observed and the morphological analysis of the intestinal wall demonstrates a inflammatory response characterized by the presence of resident macrophages in the intestinal musculature activated by the presence of substances excreted by the parasite, which activate the smooth musculature, resulting in a state of hyper controllability (Bauer 2008). For the hens assessed, an inflammatory response was also observed in the intestinal wall, although it was located in the tunica mucosa, possibly as a result of stimuli from the parasite and contributed for the occurrence of diarrhea. This may be a mechanism which explains the diarrhea signals sometimes observed in birds infected with T. gondii. Diarrhea may be explained by the fact that the myenteric neurons present an intimate association with the immune system (Spiller \& Grundy 2004), and that the presence of $T$. gondii may have induced the secretion of cytokines which unbalanced the relation between the secretion of excitatory and inhibitory neurotransmitters resulting in an increase of peristalsis.

Because of the occurrence of diarrhea in the birds infected with $T$. gondii, the dynamic of the glycoconjugates (mucins) secreted by the intestinal mucosa was also investigated in this study. It was observed that the cells marked with PAS increased $29.66 \%(p<0.05)$ whereas the ones evidenced with $A B$ only increased $12.8 \%(p<0.05)$ for the group infected with $T$. gondii. As the balance of neutral mucins became higher than the acid, it is suggested that the mucous was denser. As the neutral mucous is denser than the acid mucous, in an aqueous environment, higher capacity of protection and lubrication was assigned to the first when the mucous cells are exposed to abrasive and irritating agents (Beamish 1972). On the other hand, it must be considered that the assessment carried out in this study occurred 60 days after inoculation and, at this moment, there was possibly no presence of the parasite in the intestine, however, the birds infected with $T$. gondii presented recurrent diarrhea. Thus, it is suggested that the increase of these birds' secretion of mucin neutral would thicker the mucous covering the epithelium, protecting it from abrasion, what usually occurs during diarrhea. Similar result has also been observed when the ileum of birds in this study was assessed through the technique of detection of glycoconjugates (Shiraishi 2008). Studies on experimental infection with $T$. gondii demonstrated that the sporozoites cross the intestinal mucosa either through the enterocytes or the caliciform cells (Speer \& Dubey 1998). When the mice were coinfected with T. gondii and Nippostrongylus brasiliensis number of caliciform cells did not change; however, the mice infected only with Nippostrongylus brasiliensis presented significant increase in the number of caliciform cells (Liesenfeld et al. 2004). There are also reports on the presence of the parasite in caliciform cells of the conjunctiva of the mice minutes after inoculation (Skorich et al. 1988). However, there are no investigations assessing the dynamics of the secretion of glycoconjugates in individuals infected with $T$. gondii and cysts inside the caliciform cells were not observed in this experiment.

Remaining myenteric neurons presented general atrophy with reduction of the area of perikarion and nucleus; however, they were homogeneously distributed among the different classes of neuronal sizes and the ration between the area of the perikarion and the nucleus. Plastic changes secondary to the functional changes of the enteric neurons may occurs as a response to the infectious and inflammatory processes (Barbara \& Giorgio 2004). Preliminary studies with rats orally infected with tachyzoites from a Genotype III T. gondii strain during 30 days demonstrated that the neurons of the small intestine also presented atrophy (Sugauara et al. 2008). One possible explanation for the atrophy and reduction of the neuronal density observed would be that the neurons are dying by the apoptosis as nuclear and cellular atrophy observed in this case may be induced by immunological factors (Pollard 2006). Complimentary studies with specific markers for apoptosis are necessary to elucidate this hypothesis, and further studies with respect to the 
ultrastructure of the neurons will ensure the knowledge on the changes that might have happened inside the cell.

It was concluded that chronic infection induced by $T$. gondii oocysts resulted in the atrophy of the intestinal wall, increase of the secretion of mucins, death of neurons, and atrophy of the perikarion of the neurons of hen myenteric plexus. The changes in the myenteric plexus may be related to the cause of diarrhea observed in hens with toxoplasmosis.

\section{REFERÊNCIAS}

Arantes R.M.E., Marche H.H.F., Bahia M.T., Rossi M.A., Cunha F.Q. \& Silva J.S. 2004. Interferons-y-induced nitric oxide causes intrinsic intestinal denervation in Trypanossoma cruzi- infected mice. Am. J. Pathol. 164(4):1361-1368.

Barbara G. \& De Giorgio R. 2004. Inflammation, p.61-78. In: Spliller R. \& Grundy D. (Eds), Pathophysiology of the Enteric Nervous System: A basis for understanding functional diseases. Blackwell Publishing, Oxford.

Barbosa A.J.A. 1978. Técnica histológica para gânglios nervosos intramurais em preparados espessos. Braz. J. Med. Biol. Res. 11(2/3):95-97.

Bauer A.J. 2008. Mentation on the immunological modulation of gastrintestinal motility. Neurogastroenterol. Motil. 20(Suppl.1):81-90.

Beamish R.J. 1972. Lethal pH for white sucker Catostomus comersoni (Lacépedè). Trans. Am. Fish. Soc. 101:335-358.

Bliss S.K., Gavrilescu L.C., Alcaraz A. \& Denkers E.Y. 2001. Neutrophil depletion during Toxoplasma gondii infection leadas to impaired imunity and lethal systemic pathology. Infect. Immun. 69(8):4898-4905.

Da Silva A.V., Mendonça A.O., Pezerico S.B., Domingues P.F. \& Langoni H. 2005. Genotyping of Toxoplasma gondii strains detected in pork sausage. Parasitol. Latinoam. 60:65-68.

Dubey J.P. 1998. C.P. Beattie's Toxoplasmosis of Birds and Man. CRC Press, Boca Raton. 220p.

Dubey J.P., Saville W.J. \& Reed S.M. 2002. Prevalence of Toxoplasma gondii antibodies in domestic cats from rural Ohio. J. Parasitol. 88(4):802-803.

Dubey J.P., Navarro I.T., Graham D.H., Dahl E., Freire R.L., Prudencio L.B., Sreekumar C., Vianna M.C. \& Lehmann T. 2003. Characterization of Toxoplasma gondii isolates from free range chickens from Paraná, Brazil. Vet. Parasitol. 117:229-234.

Dubey J.P., Gennari S.M., Labruna M.B., Camargo L.M.A., Vianna M.C.B., Marcet P.L. \& Lehmann T. 2006. Characterization of Toxoplasma gondii isolates in free-range chickens from Amazon, Brazil. J. Parasitol. 92(1):36-46.

Ferguson D.J.P. \& Dubremetz J.F. 2007. The Ultrastructure of Toxoplasma gondii, p.19-48. In: Weiss L. \& Kim K. (Eds), Toxoplasma gondii: The model apicomplexan. Perspectives and Methods. Elsevier, Rio de Janeiro.

Ferreira G.L.S., Mineo J.R., Gonzaga O.J., Ferro E.A., Souza M.A. \& Santos A.A. 2004. Toxoplasma gondii and mast cell interactions in vivo and in vitro: Experimental infection approaches in Calomys callosus (Rodentia, Cricetidae). Microbes and Infection 6(2):172-181.

Freyre A., Correa O., Falcon J., Mendez J., Gonzalez M. \& Venzal J.M. 2001. Some factors influencing transmission of Toxoplasma in pregnant rats fed cysts. Parasitol. Res. 87:941-944.

Furness J.B. 2006. The Enteric Nervous System. Vol.1. Blackwell Publishing, Malden. p.1-28.

Galli S., Belinato F.C., Lucas T.M., Da Silva R.C., Longoni H \& Da Silva A.V. 2008. Infecção experimental de frangos domésticos (Gallus gallus) com cepas geneticamente de Toxoplasma gondii. Vet. Zootec. 15(3):400-606.

Garcia J.L., Navarro I.T., Ogawa L. \& Marana E.R.M. 2000. Soropre- valência do Toxoplasma gondii em galinhas (Gallus gallus domesticus) de criações domésticas, oriundas de propriedades rurais do Norte do Paraná, Brasil. Ciência Rural 30(1):123-127.

Howe D.K. \& Sibley L.D. 1995. Toxoplasma gondii comprises three clonal lineages: Correlation of parasite genotype with human disease. J. Infect. Dis. 172:1561-1566.

Jones F.E., Melton M.L., Lunde M.N. \& Eyles J.L. 1959. Experimental toxoplasmosis in chickens. J. Parasitol. 45:31-37

Kasper L., Courret N., Darche S., Luangsay S., Mennechet F., Minns L., Rachinel N., Ronet C. \& Buzoni-Gatel D. 2004. Toxoplasma gondii and mucosal immunity. Int. J. Parasitol. 34:401-409.

Kuder T., Nowak E., Szczurkowski A. \& Kuchinha J. 2003. The comparative analysis of the myenteric plexus in pigeon and hen. Anat. Histol. Embryol. 32:1-5.

Kulasiri C.S. 1965. Infection of the chicken with avirulent Toxoplasma gondii. Exp. Parasitol. 17(1):65-68.

Liesenfeld O., Dunay I.R. \& Erb E.J. 2004. Infection with Toxoplasma gondii reduces established and developing The responses induced by Nippostrongylus brasiliensis infection. Infect. Immun. 72(7):38123822.

Miranda-Neto M.H., Molinari S.L. \& Natali M.R. 2001. Diferenças regionais no número e tipo de neurônios mientéricos do íleo de ratos: comparação entre técnicas de evidenciação neuronal. Arq. Neuropsiquiatr. 59:65-69.

Myers R.B., Fredenburgh J.L. \& Grizzle W.E. 2008. Carbohydrates, p.161-187. In: Bancroft J.D. \& Gamble M. (Eds), Theory and Practice of Histological Techniques. 6th ed. Elsevier, Philadelphia.

Pollard T.D. \& Earnshaw W.C. 2006. Biologia Celular. Elsevier, Rio de Janeiro. p.753-775.

Rachinel N., Buzoni-Gatel D., Dutta C., Mennechet F.J.D., Luangsay S., Minns L.A., Grigg M.E., Tomavo S., Boothroyd J.C. \& Kasper L.H. 2004. The induction of acute ileitis by a single microbial antigen of Toxoplasma gondii. J. Immunol. 173:2725-2735.

Ruffolo B.B., Bugni F.M. \& Freire R.L. 2005. Toxoplasma gondii em galinhas de criação doméstica do município de Santa Izabel do IvaíPR, Brasil. Anais I Simpósio de Medicina Veterinária Preventiva, Programa de Pós-Graduação em Epidemiologia Experimental e Aplicada às Zoonoses, USP, São Paulo, s/p. Disponível em: http:// www.vps.fmvz.usp.br/simposio/

Ruiz A.I., Chinchilla M. \& Guerrero O. 2005. Patología em pollos inoculados oralmente com diferentes concentraciones de ooquites de Toxoplasma gondii. Parasitolol. Latinoam. 60(1/2):43-47.

Shiraishi C.S. 2008. Análise morfométrica da parede intestinal, distribuição de fibras colágenas e dinâmica de mucinas secretadas no íleo de frangos infectados por Toxoplasma gondii. Trabalho de Conclusão de Curso de Graduação em Enfermagem, Universidade Paranaense, Umuarama. 22p.

Skorich D.N., Chiappina M.L. \& Nichols B.A. 1988. Invasion of the guinea pig conjunctiva by Toxoplasma gondii. Invest. Ophthalmol. Vis. Sci. 29:1871-1880.

Speer C.A. \& Dubey J.P. 1998. Ultrastructure of early stages of infections in mice fed Toxoplasma gondii oocysts. Parasitol. 116(1):35-42.

Spiller R. \& Grundy D. 2004 Pathophysiology of the enteric nervous system: A basis for understanding functional diseases. Blackwell Publishing, Oxford. p.61-74.

Sugauara E.Y.Y., Sant'Ana D.M.G., Almeida E.C., Reis A.B., Da Silva A.V. \& Araújo E.J.A. 2008. Alterations of the myenteric plexus of the ileum and the descending colon cause by Toxoplasma gondii (genotype III). Arq. Neuropsiquiatr. 66(3A):516-523.

Tenter A.M. 1999. Current knowledge on the epidemiology of infections with Toxoplasma. Tokai J. Exp. Clin. Med. 23:391.

Tenter A.M., Heckeroth A.R. \& Weiss L.M. 2000. Toxoplasma gondii: From animals to humans. Int. J. Parasitol. 30(12):217-258. 